\title{
Crucial variations in growth and ion homeostasis of Glycine gracilis seedlings under two types of salt stresses
}

\author{
L. Shi*, S. Ma, Y. Fang, J. Xu \\ School of life sciences, Northeast Normal University, Changchun 130024, China. *Corresponding author: \\ lianxuanshi@nenu.edu.cn
}

\begin{abstract}
Based on Glycine gracilis growth and ion homeostasis testing, neutral salt (NS)and alkaline salt (AS) stress were characterized and the responses of G. gracilis were investigated.The injurious effects of AS on G. gracilis were obviously stronger than those of NS.The effects of both stresses on the $\mathrm{Na}^{+}$content and $\mathrm{Na}^{+} / \mathrm{K}^{+}$ratio were similar at low concentrations, but as the stress increased, the effects of a greater $\mathrm{Na}^{+}$content and $\mathrm{Na}^{+} / \mathrm{K}^{+}$ratio increased slowly under NS conditions, but sharply under AS. The roots of G. gracilis accumulated $\mathrm{NO}_{3}-$ and $\mathrm{H}_{2} \mathrm{PO}_{4}^{-}$, while the stems and leaves accumulated $\mathrm{C}_{2} \mathrm{O}_{4}{ }^{2}$ and $\mathrm{H}_{2} \mathrm{PO}_{4}-$ to maintain thein tracellular ion balance. The dominant intracellular anions in the stipes were $\mathrm{NO}_{3}$ - and $\mathrm{C}_{2} \mathrm{O}_{4}{ }^{2}$ - under control conditions, and $\mathrm{NO}_{3}$ - and $\mathrm{H}_{2} \mathrm{PO}_{4}$ - under salt stress. With the increasing AS, the $\mathrm{Cl}^{-}, \mathrm{NO}_{3}-$ and $\mathrm{H}_{2} \mathrm{PO}_{4}-$ concentrations decreased, and $G$. gracilis might have increased $\mathrm{SO}_{4}^{2}$ - and $\mathrm{C}_{2} \mathrm{O}_{4}^{2}$-levels to compensate for the shortage of inorganic anions. Under NS, the $\mathrm{NO}_{3}-$ and $\mathrm{C}_{2} \mathrm{O}_{4}^{2}-$ concentrations decreased, and G. gracilis might have increased $\mathrm{Cl}^{-}, \mathrm{H}_{2} \mathrm{PO}_{4}^{-}$and $\mathrm{SO}_{4}^{2}$ - levels to compensate for the shortage of inorganic anions. G. gracilis seedling showed a special nutritional metabolism and some growth adaptability under salt stress.
\end{abstract}

Keywords: Glycinegracilis, growth, ion homeostasis, saline stress, $\mathrm{pH}$ stress

Abbreviations: NS - neutral salts stress; AS - alkali salts stress; DM - dry mass; WC - water content; RGR relative growth rate.

\section{Introduction}

Land salinization, as a widespread environmental problem, is an important factor limiting agricultural productivity (Läuchli and Lüttge, 2002; Mekawy et al., 2015). Soil salinity and alkalinity seriously affect $\sim 932$ million hectares of land globally (Rao et al., 2008). In nort heastern China, alkalinized grassland covers more than $70 \%$ of the total land area. This alkalinized grassland area, where only a few alkali-tolerant halophytes can survive, is still expanding (Huang, J.C. et al, 2013). Along with over-exploitation of the earth, population growth and global climate changes will affect land usage. Therefore, the study of salt damage in plants is of growing importance. 
Natural salt-alkalinized soils are very complicated, with $\mathrm{Na}^{+}, \mathrm{Ca}^{2+}, \mathrm{Mg}^{2+}, \mathrm{K}^{+}, \mathrm{Cl}^{-}, \mathrm{SO}_{4}^{2-}, \mathrm{HCO}_{3}^{-}, \mathrm{CO}_{3}{ }^{2-}$, and $\mathrm{NO}_{3}{ }^{-}$as the main ions (Läuchli and Lüttge, 2002). $\mathrm{NaCl}, \mathrm{Na}_{2} \mathrm{SO}_{4}, \mathrm{NaHCO}_{3}$, and $\mathrm{Na}_{2} \mathrm{CO}_{3}$ are the main harmful salts in many inland areas, such as in northeastern China, where the soil became alkaline as a result of the hydrolysis of two carbonates $\left(\mathrm{NaHCO}_{3}\right.$ and $\left.\mathrm{Na}_{2} \mathrm{CO}_{3}\right)$ (Ge and Li, 1990; Zubair et al., 2012).Two neutral salts $\left(\mathrm{NaCl}\right.$ and $\left.\mathrm{Na}_{2} \mathrm{SO}_{4}\right)$ are the main salt components in saline soil, while two alkaline salts $\left(\mathrm{NaHCO}_{3}\right.$ and $\left.\mathrm{Na}_{2} \mathrm{CO}_{3}\right)$ are the main salt components in alkali soil. In previous reports, we suggested that salt stress be defined as the stress caused by neutral salts (NS), and alkali stress as the stress caused by alkaline salts (AS) (Shi and Sheng, 2005). The existence of alkali stress has been demonstrated clearly by a number of reports, which have shown it to be more severe than salt stress in various plant species (Campbell and Nishio, 2000; Hartung et al., 2002). However, to date, research on salt stress has emphasized $\mathrm{NaCl}$ as the main contributing factor (Munns and Tester, 2008; Liu et al., 2013) and little attention has been paid to alkali stress (Wang et al., 2007; Yang et al., 2008; Gao et al., 2008). Even so, there are some reports on high-pH calcareous soils (Brand et al. 2002; Nuttall et al. 2003), alkaline soil (Hartung et al., 2002), AS (El-Samad and Shaddad, 1996; Campbell and Nishio, 2000; Yang et al., 2007) and salt-alkaline mixed stress (Shi and Sheng, 2005). These reports demonstrate the existence of AS stress. Therefore, the problem of alkali stress should be recognized and investigated as thoroughly as salt stress (Wang et al., 2012). Soil salinization and alkalization usually occur together. Stress due to soil salinity generally involves osmotic stress and ion-induced injury (Munns and Tester, 2008). Comparisons of alkali and salt stress could reveal an additional effect of alkali stress due to its high $\mathrm{pH}$. A high-pH environment surrounding the roots can cause metal ions and phosphorus to precipitate (Shi and Wang, 2005; Zhang et al., 2014).With the loss of the normal physiological root functions and destruction of the root cell structure (Li et al., 2009), absorption of inorganic anions, such as $\mathrm{Na}^{+}, \mathrm{K}^{+}, \mathrm{Cl}^{-}$, $\mathrm{NO}_{3}{ }^{-}$and $\mathrm{H}_{2} \mathrm{PO}_{4}^{-}$, would be greatly affected, and thus disrupt the ionic balance (Yang et al., 2007, 2008; Chen et al., 2009). Thus, plants in alkaline soil must cope with both physiological drought and ion toxicity, and also maintain the intracellular ionic balance (Wang et al., 2011). A systematic analysis of ion contents and ratios in different plant organs are important parameters for plant growth assessment, and approaches to the study of the stress physiology. In the post-genome era, ionome research has developed into ionomics and become an important omics study, along with proteomics and metabolomics.

G. gracilis, commonly known as semi-wild soybeanbelongs to the most important legume genus. Glycineare generally divided into the wild (Glycine soja), semi-wild (G. gracilis) and cultivated soybeans (Glycine max), representing three kinds of genetic relationships in evolution (Wu et al., 2001). There are many studies on the physiological responses to salt stress in wild and cultivated soybean, but seldom reports in the semi-wild soybean (Wu et al., 2014). Having the high yield of the cultivated soybean and the high resistance of the wild soybean, the semi-wild soybean is the transition type. Studies on the physiological characteristics of stress in the semi-wild soybean reveal how these two dominant characteristics can be embodied in the same species. In this study, G. gracili seedlings were treated with different concentrations and types of salt stress. We compared the effects of NS and AS on the growth and ion balance of $G$. gracilis seedlings to elucidate the mechanisms of NS and AS damage to plants, and the physiological adaptive mechanism of plants to NS and AS. Consequently, by the study of ionomics, we provide a theoretical basis for the application in semi-wild soybean. Additionally, our data could provide a reference for the study of soybean evolution. 


\section{Materials and Methods}

\subsection{Plant materials}

Seeds of G. gracili, provided by Jilin Academy of Agriculture Science, were sown in 25 -cm-diameter plastic pots containing washed sand. Two seedlings in each pot were sufficiently watered with Hoagland's nutrient solution daily. All pots were placed outdoors and sheltered from rain. During this experiment, the humidity was $60 \%$ and temperatures were $24-28{ }^{\circ} \mathrm{C}$ in the daytimeand $17-20^{\circ} \mathrm{C}$ at night.

\subsection{Design of simulated salt conditions and stress} treatments

Two NS were mixed in a 1:1 molar ratio $(\mathrm{NaCl}$ : Na${ }_{2} \mathrm{SO}_{4}$ ) and applied to the NS stress group. For the AS stress group, two AS were mixed in a 1:1 molar ratio $\left(\mathrm{NaHCO}_{3}: \mathrm{Na}_{2} \mathrm{CO}_{3}\right)$. Within each group, the total $\mathrm{Na}^{+}$concentrations were applied at 30,60,90 and 120 $\mathrm{mmol} \cdot \mathrm{L}^{-1}$ and CDM-II electrical conductivity detector, mobile phase: $\mathrm{Na}_{2} \mathrm{CO}_{3} / \mathrm{NaHCO}_{3}=1.7 / 1.8 \mathrm{mmol} \cdot \mathrm{L}^{-1}$ ) The different salt stress groups were labeled at N1-N4 and A1-A4, respectively. The stress treatment fluid was made in Hoagland's nutrient solution. In the NS stress and AS stress groups, the $\mathrm{pH}$ levels were 6.746.75 and 9.50-0.88, respevtively. The stress treatments were applied when the seedlings were six weeks old. Thirty pots of uniformly growing seedlings were chosen and randomly divided into ten sets (three pots per set). One set was used as an untreated control, and another one was used for the growth index determination at the beginning of the treatments. The remaining eight sets were watered thoroughly every day at 17:00-18:00 with nutrient solution containing the appropriate salts for the stress treatment. Control plants were maintained by watering with nutrient solution. The entire duration of treatment was 5 days.

\subsection{Measurement of physiological indices}

Plants were harvested in the evening after the final treatment, washed by tap water and then by distilled water. The growth indices, including shoot height and root length, were measured. Then the roots, stems, leaves and stipes were separately oven-dried at 100 ${ }^{\circ} \mathrm{C}$ for $10 \mathrm{~min}$ and vacuum-dried at $75^{\circ} \mathrm{C}$ to a constant weight, after which, the dry weights were recorded. The relative growth rate $(R G R)$ was determined according to Kingsbury et al. (1984). Dry samples of plant material $(100 \mathrm{mg})$ were treated with $10 \mathrm{~mL}$ of deionized water at $100{ }^{\circ} \mathrm{C}$ for $1 \mathrm{~h}$, and the resulting extract was used to determine the contents of free inorganic ions. $\mathrm{Cl}^{-}, \mathrm{SO}_{4}{ }^{2-}, \mathrm{NO}_{3}^{-}, \mathrm{H}_{2} \mathrm{PO}_{4}^{-}$and oxalic acid concentrations in the tissue sap were determined using ion chromatography (DX-300 ion chromatographic system, AS4A-SC chromatographic column, CDMII electrical conductivity detector, mobile phase: Na${ }_{2} \mathrm{CO}_{3} / \mathrm{NaHCO}_{3}=1.7 / 1.8 \mathrm{mM}$; DIONEX, Sunnyvale, CA, USA). An atomic absorption spectrophotometer (TAS-990, Purkinje General, Beijing) was used to determine the concentrations of $\mathrm{Na}, \mathrm{K}, \mathrm{Ca}, \mathrm{Mg}, \mathrm{P}, \mathrm{Fe}$, $\mathrm{Mn}, \mathrm{B}$ and Mo atoms. ST and SA were determined according to Suomin Wang (2004) as follows:

$\mathrm{ST}=\left(\mathrm{Na}_{\text {root }}^{+} / \mathrm{K}_{\text {root }}^{+}\right) /\left(\mathrm{Na}_{\text {leave }}^{+} \mathrm{K}_{\text {leave }}^{+}\right)$and $\mathrm{SA}=\left(\mathrm{Na}_{\text {soil }}^{+} / \mathrm{K}_{\text {soil }}^{+}\right) /\left(\mathrm{Na}_{\text {plant }}^{+} / \mathrm{K}_{\text {plant }}^{+}\right)$.

\subsection{Statistical analyses}

All data were expressed as means $\pm \mathrm{SE}$, and each mean value was calculated from three replicates. Data were analyzed by one-way analysis of variance (ANOVA) using the statistical software SPSS 17.0 (SPSS Inc., Chicago, USA). The treatment values were compared using an F-test. The term significant indicates differences for which $P \leq 0.05$. 


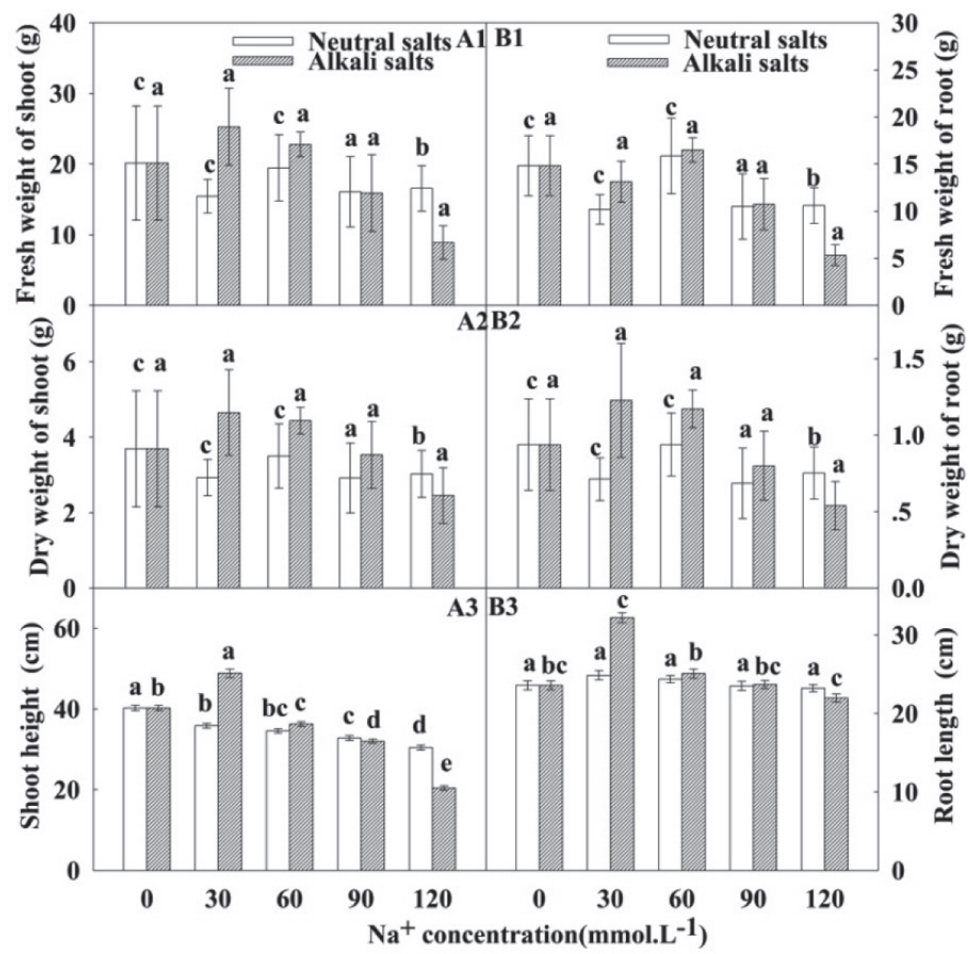

Figure 1. Effects of different type salts stresses on the fresh weight of shoot (A1), the fresh weight of root (B1), the dry weight of shoot (A2), the dry weight of root (B2), the shoot height (A3), the root length (B3) of G. gracilis seedlings. The values are the means of three replicates. Means followed by different letters in the samestress type are significantly different at $P<0.05$ according to Duncan's method. Neutral salts stress: $\mathrm{NaCl}_{2} \mathrm{Na}_{2} \mathrm{SO}_{4}=1: 1$; Alkaline salts stress: $\mathrm{NaHCO}_{3}: \mathrm{Na}_{2} \mathrm{CO}_{3}=1: 1$

\section{Results}

\subsection{Growth}

Along with the increase in $\mathrm{Na}^{+}$concentrations under the two types of salt stresses, the fresh weights of shoots and roots, the dry weights of shoots and roots, the shoot heights and the root lengths of $G$. gracilis seedlings all significant decreased (Figure $1, P<0.01$ ) and the decreases under the AS treatment were more obvious than under the NS treatment. The $R G R$ and $W C$ of G. gracilis seedlings are shown in Figure 1.
The $R G R$ of G. gracilis decreased with the increasing salt stress, and the degree of the decrease was greater under AS stress than under NS stress. The $R G R$ of the aboveground portion of G.gracilis was more significant than that of the underground. With the increase in the $\mathrm{Na}^{+}$concentrations, the $W C$ of roots, stems and petioles decreased, but they did not reach significant levels under either salt stress and there was no significant difference between the two salt stresses $(P>0.05)$. The $W C$ of leaves was significantly decreased, especially under the AS stress $(P<0.01)$. However, under AS, when the $\mathrm{Na}^{+}$concentrations was $30 \mathrm{mmol} \cdot \mathrm{L}^{-1}$, 
the fresh weights of shoots, the dry weights of shoots and roots, the shoot heights and the root lengths of $G$. gracilis seedlings were significantly higher than in the control. This indicated a special compensatory effect.

\subsection{Cations}

For both types of salt stress, the $\mathrm{Na}^{+}$contents of roots, stems, petioles and leaves were all higher than those of controls. The $\mathrm{Na}^{+}$contents in stems, leaves and petioles also increased with the increase in stress intensity. However, under the same concentrations, the $\mathrm{Na}^{+}$content was higher in the AS than that in the NS treatment group and the increasing trend in the AS were greater than that in the NS. In the root system of $G$. gracilis, the $\mathrm{Na}^{+}$content presented an increasing trend as the stress intensity increased under NS conditions, but presented a decreasing trend under AS conditions (Figure 2, A1, B1; $P<0.01$ ). Under the NS treatment, mainly the underground organs accumulated $\mathrm{Na}^{+}$, but under the AS treatment, mainly the aboveground organs accumulated $\mathrm{Na}^{+}$.

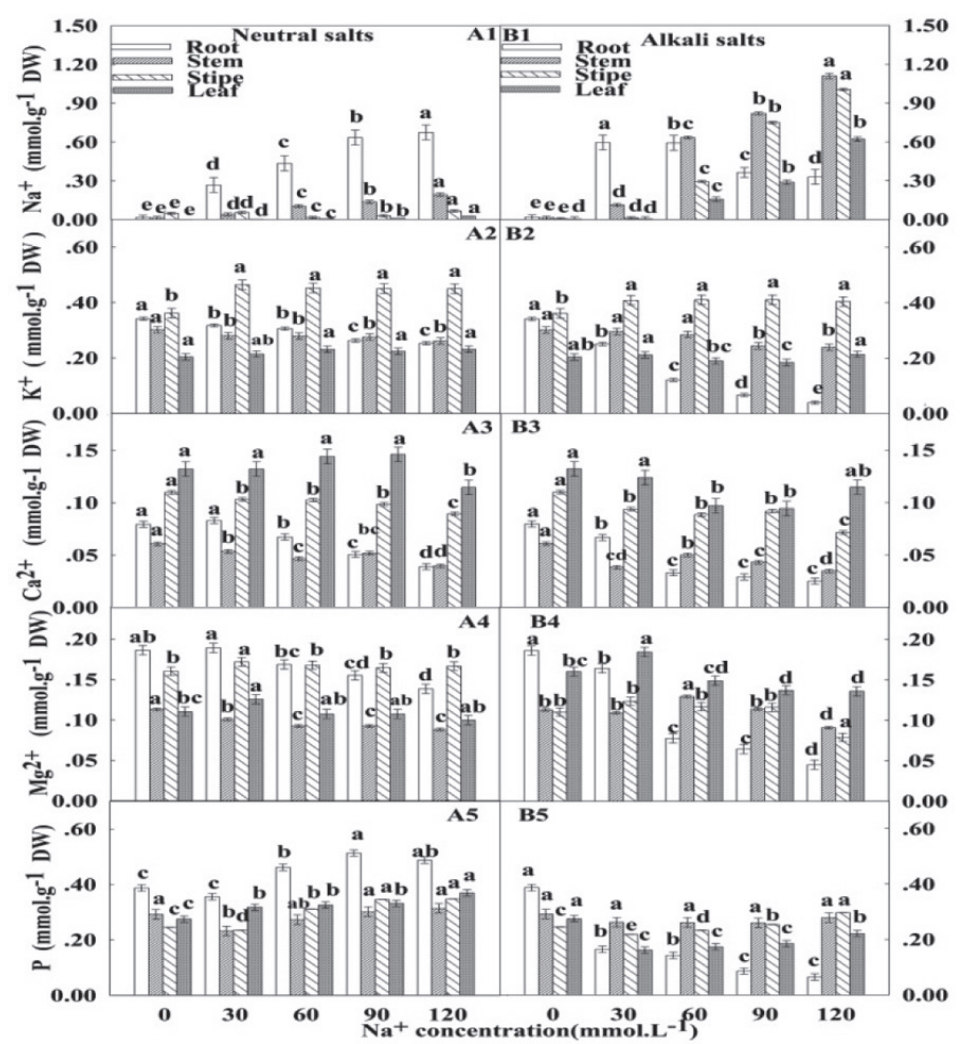

Figure 2. Effects of different type salts stress on contents of $\mathrm{Na}^{+}(\mathrm{A} 1, \mathrm{~B} 1), \mathrm{K}^{+}(\mathrm{A} 2, \mathrm{~B} 2), \mathrm{Ca}^{+}(\mathrm{A} 3, \mathrm{~B} 3) \mathrm{Mg}^{+},(\mathrm{A} 4$, B4), and P (A5, B5) of G.gracilis seedlings; The values are the means of three replicates. Means followed by different letters in the same stress type aresignificantly different at $P<0.05$ according to Duncan's method. Saline stress: Neutral salts stress: $\mathrm{NaCl}: \mathrm{Na}_{2} \mathrm{SO}_{4}=1: 1 ;$ Alkaline salts stress: $\mathrm{NaHCO}_{3}: \mathrm{Na}_{2} \mathrm{CO}_{3}=1: 1$. 
Under both types of salt stress, the $\mathrm{Ca}^{2+}$ and $\mathrm{K}^{+}$ contents of G. gracilis seedlings' roots and stems showed declining trends and were lower than those of the controls. However, the degree of decrease under the AS treatment was significantly greater than that under the NS treatment (Figure 2, A2, B2, A3, B3; $P<0.01)$. There were no obvious differences in the $\mathrm{Ca}^{2+}$ and $\mathrm{K}^{+}$contents in leaves under the different $\mathrm{Na}^{+}$concentrations of NS, but there were significant decreasing trends under AS $(P<0.05)$. The $\mathrm{K}^{+}$contents in petioles were significantly higher than that of the control under both types of salt stress $(P$ $<0.01)$. However, there were not significant differences between the different $\mathrm{Na}^{+}$concentrations $(P$ $>0.05$ ). The $\mathrm{Ca}^{2+}$ contents' trends in petioles were similar to those in roots and stems under the different salt stresses. The main organ for $\mathrm{K}^{+}$accumulation changed from underground to above ground with the increased $\mathrm{Na}^{+}$concentrations under both types of salt stress. For NS, petioles and leaves were the main organs for $\mathrm{K}^{+}$accumulation, but $\mathrm{K}^{+}$could be only accumulated in petioles under AS. $\mathrm{Ca}^{2+}$ showed no significant accumulation with the increase of $\mathrm{Na}^{+}$ concentrations. Under the same concentration stress, the $\mathrm{Ca}^{2+}$ and $\mathrm{K}^{+}$contents of each organ were all lower under AS than under NS treatments.

The $\mathrm{Mg}^{2+}$ content in roots, stems and leaves of $G$. gracilis seedlings showed decreasing trends under both kinds of salt stress, and especially under AS, where it decreased more significantly. With the same $\mathrm{Na}^{+}$concentration stress, the $\mathrm{Mg}^{2+}$ content in roots was higher under NS, but in stems and leaves it was higher under AS. The $\mathrm{Mg}^{2+}$ content in petioles showed no significant change under higher concentrations of NS, but significantly decreased under high concentrations of AS (Figure 2, A4, B4; $P<$ $0.01)$. The $\mathrm{P}^{3+}$ contents in roots, stems, petioles and leaves showed significantly increasing trends under NS, and were all higher than that of control.
However, the $\mathrm{P}^{3+}$ content in roots showed a decreasing trend and were significantly lower than controls. In stems and leaves the $\mathrm{P}^{3+}$ contents showed increasing trends, and in petioles there were no significant differences between different $\mathrm{Na}^{+}$concentration under AS. However, the $\mathrm{P}^{3+}$ contents in each organ were all lower than those in the controls (Figure 2, A5, B5; $P<0.01)$. With an increase in the two types of salt stress intensity, the $\mathrm{Fe}^{3+}$ contents in the roots showed no significant differences, but in stems, petioles and leaves it showed a significant increasing trend (Figure 3, the $\mathrm{A} 1, \mathrm{~B} 1 ; P<0.01)$. The $\mathrm{P}^{3+}, \mathrm{Mg}^{2+}$ and $\mathrm{Fe}^{3+}$ contents in G. gracilis seedlings moved from the underground organs to the aboveground organs under both kinds of salt stress, but under AS, the change was more significant.

The $\mathrm{Mn}^{2+}$ contents in roots, stems, petioles and leaves of G. gracilis seedlings showed increasing trends along as the AS stress intensity increased, and they were significantly higher than those of the NS and control. However, the $\mathrm{Mn}^{2+}$ contents in stems, petioles and leaves showed decreasing trends under NS, which were also greater than those of the control, and in the roots no regular changes were detected (Figure 3, A2, B2; $P<0.01$ ). The $\mathrm{Mo}^{2+}$ contents in roots, stems, petioles and leaves of G. gracilis seedlings showed decreasing trends as both types of salt stress intensities increased. Under the same $\mathrm{Na}^{+}$concentration stress, the $\mathrm{Mo}^{2+}$ contents under AS were higher than those of the NS and control, except in roots (Figures 3, A3, B3; $P<0.01)$.

The changes in the $\mathrm{B}^{3+}$ contents were similar to those of $\mathrm{Mo}^{2+}$; however, with the same $\mathrm{Na}^{+}$concentrations, the $\mathrm{B}^{3+}$ contents under NS were significantly higher than those under AS and the controls (Figure 3, A4, B4; $P<0.01$ ). 


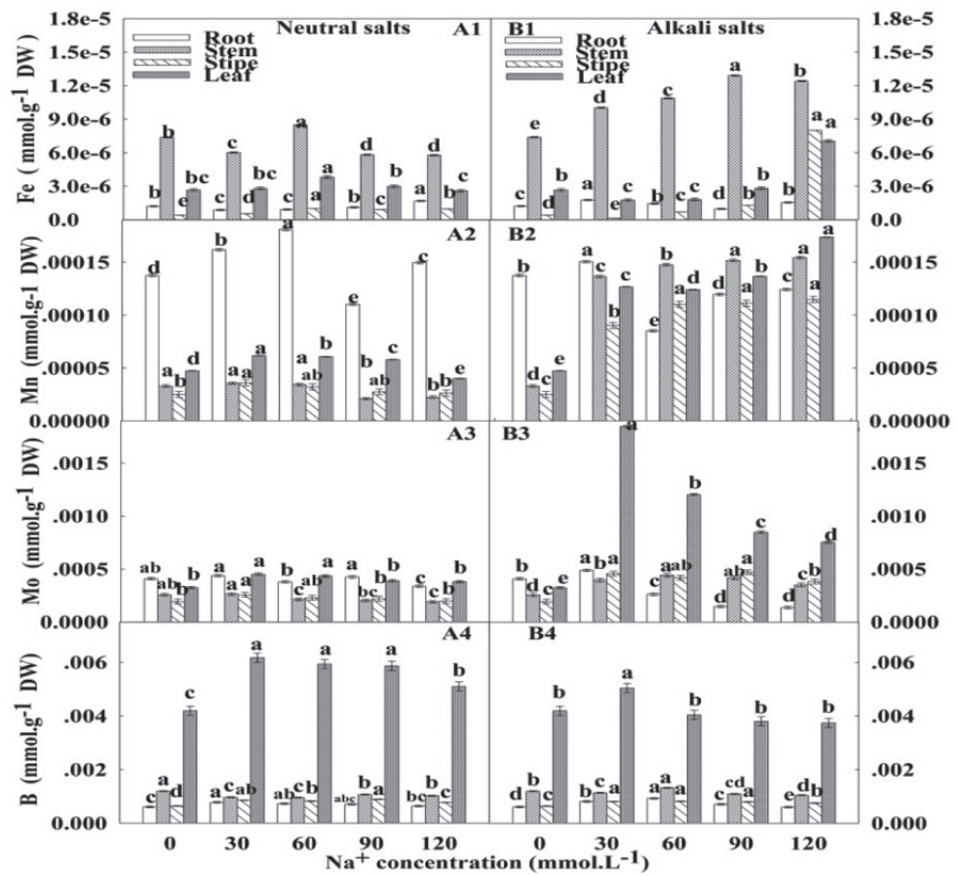

Figure 3. Effects of different type salts stress on contents of Fe (A1, B1), Mn (A2, B2), Mo (A3, B3) and B (A4, B4) of G.gracilis seedlings; The values are the means of three replicates. Means followed by different letters in the same stress type aresignificantly different at $P<0.05$ according to Duncan's method.Neutral salts stress: $\mathrm{NaCl}: \mathrm{Na}_{2} \mathrm{SO}_{4}=1: 1 ;$ Alkaline salts stress: $\mathrm{NaHCO}_{3}: \mathrm{Na}_{2} \mathrm{CO}_{3}=1: 1$.

\subsection{Anions}

The $\mathrm{Cl}^{-}$contents in stems, petioles and leaves of G. gracilis seedlings were higher under the two salt stresses than in the controls, and the $\mathrm{Cl}^{-}$content in each organ increased as the $\mathrm{Na}^{+}$concentration increased. $\mathrm{Cl}^{-}$contents were significantly higher under NS than under AS at the same $\mathrm{Na}^{+}$concentrations. Additionally, the $\mathrm{Cl}^{-}$concentrations' changing trend in the roots was the same as in other organs under NS. However, the $\mathrm{Cl}^{-}$concentrations were significantly lower under AS than under control conditions, and showed a gradually decreasing trend as the $\mathrm{Na}^{+}$concentration increased (Figure 4, A1, B1; $P<0.01$ ). The experimental results showed that $\mathrm{Cl}^{-}$contents were mostly accumulated in the roots and were significantly higher than in the stems, petioles and leaves under NS. Along with the increasing of stress strength, the distribution of $\mathrm{Cl}^{-}$changed under AS, from the underground to the above ground. $\mathrm{Cl}^{-}$in stems, petioles and leaves accumulated only under a high $\mathrm{Na}^{+}$concentration of AS. The $\mathrm{H}_{2} \mathrm{PO}_{4}-$ content' s accumulation behavior was consistent with $\mathrm{Cl}^{-}$in different organs under both types of salt treatments (Figure 4, A3, B3; $P<0.01)$. As the $\mathrm{Na}^{+}$concentration of both types of salt stress increased, the changes in the $\mathrm{NO}^{3}$-contentsin roots, stems, petioles and leaves of the G. gracilis seedlings were similar. The $\mathrm{NO}_{3}-$ content decreased in roots, was not significantly different in stems, and increased in petioles and leaves. 


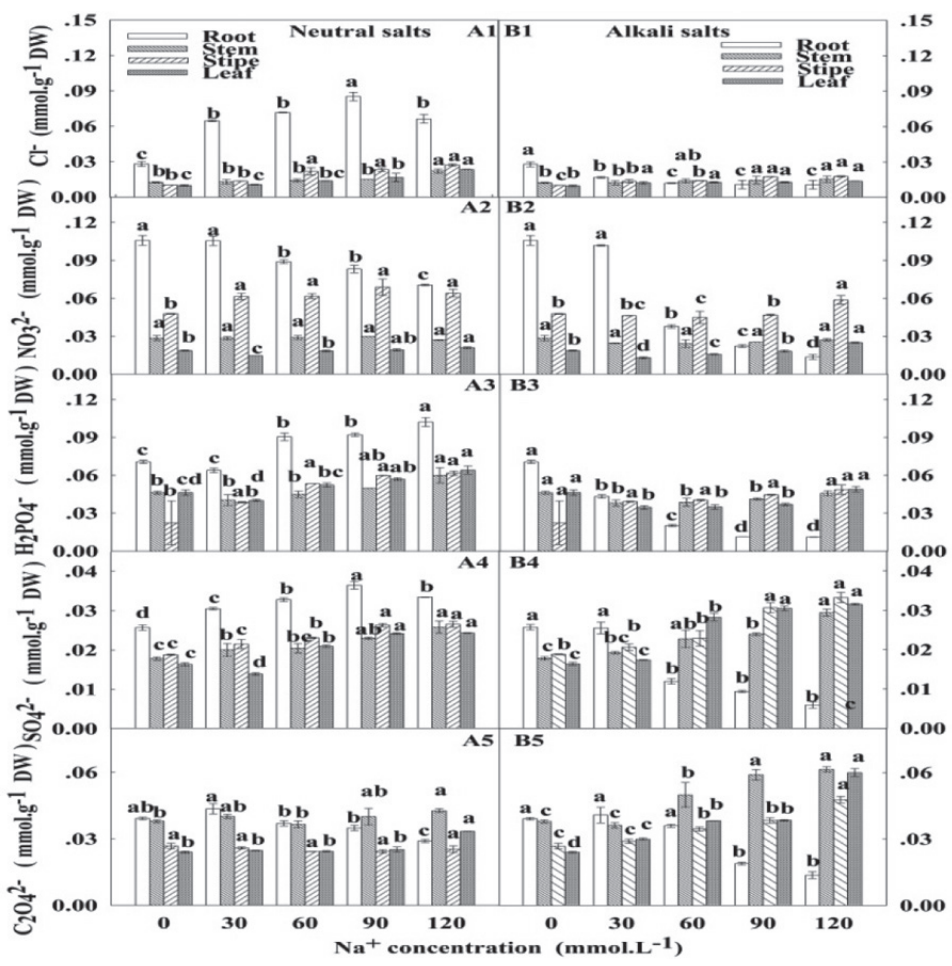

Figure 4. Effects of different type salts stress on contents of $\mathrm{Cl}-(\mathrm{A} 1, \mathrm{~B} 1), \mathrm{NO}_{3}-(\mathrm{A} 2, \mathrm{~B} 2), \mathrm{H}_{2} \mathrm{PO}_{4^{-}}(\mathrm{A} 3, \mathrm{~B} 3)$, $\mathrm{SO}_{4}^{2-}(\mathrm{A} 4, \mathrm{~B} 4)$ and $\mathrm{C}_{2} \mathrm{O}_{4}{ }_{4}^{--}(\mathrm{A} 5, \mathrm{~B} 5)$ of $G$. gracilis seedlings; The values are the means of three replicates. Means followed by different letters in the same stress type aresignificantly different at $P<0.05$ according to Duncan's method. Neutral salts stress: $\mathrm{NaCl}: \mathrm{Na}_{2} \mathrm{SO}_{4}=1: 1 ;$ Alkaline salts stress: $\mathrm{NaHCO}_{3}: \mathrm{Na}_{2} \mathrm{CO}_{3}=1: 1$.

At the same time, the $\mathrm{NO}_{3}-$ content was lower under stress treatments than in controls. The $\mathrm{NO}_{3}$ - contents under AS were lower than under NS and the range of changes under AS were greater than under NS (Figure 4, A2, B2; $P<0.01)$.

The $\mathrm{SO}_{4}{ }^{2-}$ contents in roots, stems, petioles and leaves increased with increasing $\mathrm{Na}^{+}$concentrations of NS, showing accumulation specificity along with the increased stress. The $\mathrm{SO}_{4}{ }^{2-}$ contents in roots were higher than in stems, petioles and leaves. The $\mathrm{SO}_{4}{ }^{2-}$ contents in roots decreased with the increasing $\mathrm{Na}^{+}$concentrations of AS, but increased in stems, petioles and leaves. With the AS intensity increased, the distribution of $\mathrm{SO}_{4}{ }^{2-}$ changed from the underground to the above ground organs (Figure 4, A4, B4; $P<0.01$ ). $\mathrm{C}_{2} \mathrm{O}_{4}{ }^{2-}$ accumulated mostly in stems in the whole plant under both types of salt stress. Under NS, the $\mathrm{C}_{2} \mathrm{O}_{4}{ }^{2-}$ contents in roots decreased linearly with the increasing salinity, but in the stems, petioles and leaves there was an initial decrease, followed by increases under different treatments. This showed that the roots could accumulate $\mathrm{C}_{2} \mathrm{O}_{4}{ }^{2-}$ only in low concentrations, but stems, petioles and leaves could accumulate it at both low and high concentrations. 
The $\mathrm{C}_{2} \mathrm{O}_{4}^{2-}$ in roots decreased with the increasing salinity under AS. The $\mathrm{C}_{2} \mathrm{O}_{4}^{2-}$ in stems, petioles and leaves showed trends of increasing first, and then decreasing, with the increasing salinity. With the increase of AS intensity, the distribution of $\mathrm{C}_{2} \mathrm{O}_{4}{ }^{2-}$ changed. Under high concentrations of AS, the $\mathrm{C}_{2} \mathrm{O}_{4}{ }^{2-}$ in stems, petioles and leaves specifically accumulated (Figure $4, \mathrm{~A} 5, \mathrm{~B} 5 ; P<0.01$ ).

\subsection{Ion balance}

\subsection{1. $\mathrm{Na}^{+} / \mathrm{K}^{+}$}

With the increasing levels of NS and AS, the $\mathrm{Na}+/ \mathrm{K}+$ in different organs of $G$. gracilis seedlings rose, but the extent under AS was more significant than under NS. Under the same stress intensity, $\mathrm{Na}^{+} \mathrm{K}^{+}$under AS was higher than under NS. Under both types of salt stresses, $\mathrm{Na}^{+} / \mathrm{K}^{+}$gradually moved from underground organs to above ground organs, and the reduction range under NS was greater than under AS. $\mathrm{Na}^{+} / \mathrm{K}^{+}$values in roots were the highest under AS at all treatment levels (Table 1). The damage under AS was greater than under NS, and the damage to the underground parts of $G$. gracilis seedlings was greater than to the above ground part under both kinds of salt stress. The roots suffered the most serious damage under AS.

\subsubsection{Selective absorption of $\mathrm{Na}^{+}$and $\mathrm{K}^{+}$}

SA and ST were used to measure the selective absorption of $\mathrm{Na}^{+}$and $\mathrm{K}^{+}$. ST shows the capability of roots to transport $\mathrm{Na}^{+}$upward and $\mathrm{K}^{+}$down ward. SA shows the roots selective absorption of $\mathrm{K}^{+}$and blockage of $\mathrm{Na}^{+}$ absorption. A higher ST value indicated that the root controlled $\mathrm{Na}^{+}$uptake and capability of $\mathrm{K}^{+}$transport to the leaves were stronger, indicating that the selective transportation ability of the root was stronger. Meanwhile, a higher SA value indicated that the root refused $\mathrm{Na}^{+}$absorption and its selective absorption of $\mathrm{K}^{+}$was stronger, indicating thatthe selective absorption capability of the root was stronger (Wang et al., 2004).

Table1. The ratio of $\mathrm{Na}^{+} / \mathrm{K}^{+}$in root, stem, stipe, leaf and SA, ST of $G$. graciliseed ling under different type salts stresses. Neutral salts stress: $\mathrm{NaCl}: \mathrm{Na}_{2} \mathrm{SO}_{4}=1: 1 ;$ Alkaline salts stress: $\mathrm{NaHCO}_{3}: \mathrm{Na}_{2} \mathrm{CO}_{3}=1: 1$

\begin{tabular}{|c|c|c|c|c|c|c|}
\hline $\begin{array}{l}\mathrm{Na}^{+} \text {concentration } \\
(\mathrm{mM})\end{array}$ & Root & Stem & Stipe & Leaf & SA & ST \\
\hline 0 & $0.048 \pm 0.00 \mathrm{le}$ & $0.042 \pm 0.00 \mathrm{le}$ & $0.014 \pm 0.00 \mathrm{ldi}$ & $0.015 \pm 0.000 \mathrm{e}$ & $0.093 \pm 0.00 \mathrm{Idj}$ & $3.192 \pm 0.577 \mathrm{eh}$ \\
\hline \multicolumn{7}{|l|}{ Neutral salts } \\
\hline 30 & $0,848 \pm 0,001 \mathrm{~d}$ & $0.143 \pm 0,001 d$ & $0.012 \pm 0,001 \mathrm{~d}$ & $0.018 \pm 0,000 \mathrm{~d}$ & $17,164 \pm 0.577 \mathrm{c}$ & $45,818 \pm 0,577 \mathrm{c}$ \\
\hline 60 & $1.426 \pm 0.002 \mathrm{c}$ & $0.379 \pm 0.005 \mathrm{c}$ & $0.036 \pm 0.001 \mathrm{c}$ & $0.025 \pm 0.000 \mathrm{c}$ & $19.306 \pm 0.057 \mathrm{~b}$ & $56.646 \pm 0.050 \mathrm{a}$ \\
\hline 90 & $2.416 \pm 0.00 \mathrm{lb}$ & $0.499 \pm 0.00 \mathrm{lb}$ & $0.067 \pm 0.002 \mathrm{~b}$ & $0.050 \pm 0.002 \mathrm{~b}$ & $19.161 \pm 0.004 b$ & $48.092 \pm 0.970 \mathrm{~b}$ \\
\hline 120 & $2.670 \pm 0.002 \mathrm{a}$ & $0.743 \pm 0.009 \mathrm{a}$ & $0,149 \pm 0,003 \mathrm{a}$ & $0.113 \pm 0.000 \mathrm{a}$ & $21,299 \pm 0.072 \mathrm{a}$ & $23.542 \pm 1.520 \mathrm{~d}$ \\
\hline \multicolumn{7}{|l|}{ Alkalinesalts } \\
\hline 30 & $2.368 \pm 0.002 \mathrm{i}$ & $0.383 \pm 0.00 \mathrm{li}$ & $0,03 \mathrm{l} \pm 0,00 \mathrm{li}$ & $0,017 \pm 0,000 \mathrm{i}$ & $6.915 \pm 0,003 \mathrm{f}$ & $138.008 \pm 0.289 f$ \\
\hline 60 & $4.866 \pm 0.00 \mathrm{lh}$ & $2.223 \pm 0.00 \mathrm{lh}$ & $0.716 \pm 0.00 \mathrm{lh}$ & $0.826 \pm 0.00 \mathrm{lh}$ & $5.149 \pm 0.002 \mathrm{~h}$ & $5.890 \pm 0.057 \mathrm{~g}$ \\
\hline 90 & $5.457 \pm 0.001 \mathrm{~g}$ & $3.362 \pm 0.00 \mathrm{lg}$ & $1.829 \pm 0.00 \mathrm{lg}$ & $1.563 \pm 0.003 \mathrm{~g}$ & $5.238 \pm 0.002 \mathrm{~g}$ & $3.49 \mathrm{l} \pm 0.350 \mathrm{~h}$ \\
\hline 120 & $8.385 \pm 0.002 \mathrm{f}$ & $4.640 \pm 0.002 \mathrm{f}$ & $2.486 \pm 0.003 \mathrm{f}$ & $2.913 \pm 0.004 \mathrm{f}$ & $5.012 \pm 0.024 \mathrm{i}$ & $2.878 \pm 0.002 \mathrm{~h}$ \\
\hline
\end{tabular}


The experimental result showed that, along with the increase in the two types of salt stress, the ST values of $G$. gracilis seedlings first increased and then decreased, and the proportion of treatments were greater than the control. However, there also were some differences between NS and AS. Under NS, ST rose when the concentration of $\mathrm{Na}^{+}$was $15-60 \mathrm{mmol} \cdot \mathrm{L}^{-1}$ then decreased at $60-120 \mathrm{mmol} \cdot \mathrm{L}^{-1}$. While under AS, ST rose significantly when the concentration of $\mathrm{Na}^{+}$ was $15-30 \mathrm{mmol} \cdot \mathrm{L}^{-1}$. The increase dintensity under AS was greater than that under NS, which were $834 \%$ and $301 \%$, respectively. When the stress intensity was higher than $30 \mathrm{mmol} \cdot \mathrm{L}^{-1}$, ST significantly decreased, to $0.10 \%, 0.07 \%$ and $0.12 \%$ of NS, respectively.

Under the two different types of salt stress, the SA values of $G$. gracilis seedlings were all higher than those of the control, and there were no significant changes among the different $\mathrm{Na}^{+}$concentration treatments. However, SA value sunder NS were greater than those under AS. At the same $\mathrm{Na}^{+}$concentrations, the SA of NS were $343 \%, 248 \%, 375 \%, 366 \%$ and $425 \%$ of AS, respectively.

\subsubsection{Ion percentage}

Under control conditions, G. gracilis seedling roots the accumulated cations were mainly $\mathrm{P}^{3+}$ and $\mathrm{K}^{+}$, and the accumulated anions were mainly $\mathrm{NO}^{3-}$ and $\mathrm{H}_{2} \mathrm{PO}_{4}^{-}$. The accumulated ions in stems and leaves were mainly cationic $\mathrm{P}^{3+}$ and $\mathrm{K}^{+}$, and anionic $\mathrm{H}_{2} \mathrm{PO}_{4}-$ and $\mathrm{C}_{2} \mathrm{O}_{4}{ }^{2-}$. Petioles mainly accumulated in the cations of $\mathrm{P}^{3+}$ and $\mathrm{K}^{+}$and the anions of $\mathrm{NO}^{3-}$ and $\mathrm{C}_{2} \mathrm{O}_{4}^{2-}$ (Table 2-3).

Under NS, when the stress concentration was low, the accumulated cations in roots were mainly $\mathrm{P}^{3+}$ and $\mathrm{K}^{+}$. But when the stress concentration became higher, $\mathrm{Na}+$ became the major cation instead of $\mathrm{P}^{3+}$ and $\mathrm{K}^{+}$. The accumulated anions for roots were mainly $\mathrm{NO}_{3}^{-}$ and $\mathrm{H}_{2} \mathrm{PO}_{4}-$. The accumulated cations of stem and leaf were mainly $\mathrm{P}^{3+}$ and $\mathrm{K}^{+}$, and anions were mainly $\mathrm{NO}_{3}-$ and $\mathrm{H}_{2} \mathrm{PO}_{4}-$. Petioles mostly accumulated cationic $\mathrm{P}^{3+}$ and $\mathrm{K}^{+}$, and anionic $\mathrm{H}_{2} \mathrm{PO}_{4}-$ and $\mathrm{NO}_{3}-$ (Table 2-3). With the increase of NS, the percentages of $\mathrm{Na}^{+}, \mathrm{P}^{3+}$, $\mathrm{SO}_{4}{ }^{2-}, \mathrm{Cl}^{-}$and $\mathrm{H}_{2} \mathrm{PO}_{4}-$ in roots and petioles of G. gracilis seedlings increased and percentages of $\mathrm{K}^{+}, \mathrm{Mg}^{2+}, \mathrm{Mo}^{2+}$, $\mathrm{NO}_{3}-$ and $\mathrm{C}_{2} \mathrm{O}_{4}^{2-}$ decreased. Percentages of $\mathrm{Na}^{+}, \mathrm{P}^{3+}$, $\mathrm{SO}_{4}{ }^{2-}$ and $\mathrm{Cl}^{-}$in stems increased and percentages of $\mathrm{K}^{+}$, $\mathrm{Mg}^{2+}, \mathrm{Mo}^{2+}, \mathrm{NO}_{3}-$ and $\mathrm{C}_{2} \mathrm{O}_{4}{ }^{2-}$ decreased. In blades, the percentages of $\mathrm{Na}^{+}, \mathrm{P}^{3+}, \mathrm{Mo}^{2+}, \mathrm{SO}_{4}^{2-}$ and $\mathrm{Cl}^{-}$increased, but percentages of $\mathrm{K}^{+}, \mathrm{Mg}^{2+}, \mathrm{NO}_{3}-$ and $\mathrm{C}_{2} \mathrm{O}_{4}{ }^{2-}$ decreased. Compared with other cations, percentages of $\mathrm{Fe}^{2+}, \mathrm{Mn}^{2+}, \mathrm{B}^{3+}$ and $\mathrm{Mo}^{2+}$ were very small, less than $1 \%$ of the total cations. The percentage of $\mathrm{Fe}^{2+}$ was the smallest and its percentage content had no obvious difference with the control group (Table 2-3).

Under AS, the accumulated cations in roots were mainly $\mathrm{Na}^{+}$and $\mathrm{K}^{+}$atlow concentrations and $\mathrm{Na}^{+}$athigh stress concentrations, and the accumulated anions were mainly $\mathrm{NO}_{3}$-and $\mathrm{H}_{2} \mathrm{PO}_{4}$ - The main accumulated cations in stems and petioles were $\mathrm{P}^{3+}$ and $\mathrm{K}^{+}$at low concentrations and $\mathrm{Na}^{+}$at high stress concentrations, and the accumulated anions were $\mathrm{NO}_{3}-$ and $\mathrm{H}_{2} \mathrm{PO}_{4}$ - The accumulated cations in leaves were mainly $\mathrm{Mg}^{2+}$ and $\mathrm{K}^{+}$at low concentrationsand $\mathrm{Na}^{+}$at high stress concentrations, and the accumulated anions were $\mathrm{NO}_{3}-$ and $\mathrm{H}_{2} \mathrm{PO}_{4}-$. Under AS, the percentage of $\mathrm{Na}^{+}, \mathrm{C}_{2} \mathrm{O}_{4}{ }^{2-}, \mathrm{Cl}-$ and $\mathrm{SO}_{4}{ }^{2-}$ in roots and stem sincreased, but the percentage of $\mathrm{K}^{+}, \mathrm{Mg}^{+}, \mathrm{Ca}^{2+}, \mathrm{P}^{3+}, \mathrm{Mo}^{2+}, \mathrm{NO}_{3}-$ and $\mathrm{H}_{z} \mathrm{PO}_{4}$-decreased. The percentages of $\mathrm{Na}^{+}, \mathrm{SO}_{4}{ }^{2-}, \mathrm{C}_{2} \mathrm{O}_{4}{ }^{2-}, \mathrm{Cl}$-and $\mathrm{H}_{2} \mathrm{PO}_{4}$ - in petioles increased, and the percentages of $\mathrm{K}^{+}, \mathrm{Mg}^{2+}, \mathrm{Ca}^{2+}, \mathrm{P}^{3+}, \mathrm{Mo}^{2+}$ and $\mathrm{NO}_{3}-$ decreased. The percentage of $\mathrm{Na}^{+}, \mathrm{Mo}^{2+}, \mathrm{SO}_{4}^{2-}, \mathrm{C}_{2} \mathrm{O}_{4}{ }^{2-}$ in leaves increased, and the percentage of $\mathrm{K}^{+}, \mathrm{Mg}^{2+}, \mathrm{Ca}^{2+}, \mathrm{P}^{3+}, \mathrm{NO}_{3}-$ and $\mathrm{H}_{2} \mathrm{PO}_{4}$-decreased. Compared with other cations, the percentages of $\mathrm{Fe}^{2+}, \mathrm{Mn}^{2+}, \mathrm{B}^{3+}$ and $\mathrm{Mo}^{2+}$ were very small, less than $1 \%$ of the total cations. The percentage of $\mathrm{Fe}^{2+}$ content was the smallest, and its percentage content had no obvious difference with the control group (Table 2-3). 
Table 2. The percentages of different cations in root, stem, stipe and leaf of G. gracili seedlings under different type salts stresses. Neutral salts stress: $\mathrm{NaCl}: \mathrm{Na}_{2} \mathrm{SO}_{4}=1: 1$; Alkaline salts stress: $\mathrm{NaHCO}_{3}: \mathrm{Na}_{2} \mathrm{CO}_{3}=1: 1$.

\begin{tabular}{|c|c|c|c|c|c|c|c|c|c|}
\hline $\begin{array}{l}\mathrm{Na}^{+} \text {concentration } \\
(\mathrm{mM})\end{array}$ & 0 & $\begin{array}{l}\text { NS } \\
\mathbf{3 0}\end{array}$ & 60 & 90 & 120 & $\begin{array}{l}\text { AS } \\
30\end{array}$ & 60 & 90 & 120 \\
\hline $\mathrm{Root} \mathrm{Na}[\%]$ & 1.634 & 22.128 & 30.253 & 39.243 & 42.355 & 47.845 & 61.154 & 59.559 & 65.367 \\
\hline $\mathrm{K}[\%]$ & 33.754 & 26.109 & 21.223 & 16.246 & 15.865 & 20.204 & 12.567 & 10.915 & 7.795 \\
\hline $\mathrm{Ca}[\%]$ & 7.849 & 6.836 & 4.675 & 3.13 & 2.446 & 5.365 & 3.405 & 4.756 & 4.952 \\
\hline $\mathrm{Mg}[\%]$ & 18.406 & 15.57 & 11.713 & 9.591 & 8.684 & 13.229 & 8.019 & 10.558 & 8.922 \\
\hline P [\%] & 38.242 & 29.244 & 32.047 & 31.713 & 30.579 & 13.239 & 14.724 & 14.052 & 12.793 \\
\hline $\mathrm{Fe}[\%]$ & 0.000119 & 0.000071 & 0.000063 & 0.000068 & 0.000105 & 0.000141 & 0.000149 & 0.000162 & 0.000314 \\
\hline Mn [\%] & 0.014 & 0.013 & 0.013 & 0.007 & 0.01 & 0.012 & 0.009 & 0.020 & 0.025 \\
\hline B [\%] & 0.060 & 0.064 & 0.051 & 0.044 & 0.040 & 0.065 & 0.096 & 0.116 & 0.119 \\
\hline Мo [\%] & 0.040 & 0.036 & 0.026 & 0.026 & 0.021 & 0.039 & 0.027 & 0.024 & 0.027 \\
\hline Stem $\mathrm{Na}[\%]$ & 1.636 & 5.669 & 13.233 & 15.973 & 21.615 & 13.789 & 46.54 & 55.337 & 63.237 \\
\hline $\mathbf{K}[\%]$ & 38.616 & 39.555 & 34.955 & 32.032 & 29.111 & 36.048 & 20.936 & 16.461 & 13.63 \\
\hline Ca [\%] & 7.781 & 7.585 & 5.854 & 6.048 & 4.441 & 4.67 & 3.68 & 2.91 & 1.983 \\
\hline $\mathbf{M g}[\%]$ & 14.464 & 14.227 & 11.618 & 10.777 & 9.826 & 13.317 & 9.512 & 7.677 & 5.185 \\
\hline $\mathrm{P}[\%]$ & 37.312 & 32.770 & 34.178 & 35.026 & 34.882 & 31.972 & 19.191 & 17.502 & 15.876 \\
\hline $\mathrm{Fe}[\%]$ & 0.000150 & 0.000012 & 0.000115 & 0.000128 & 0.000186 & 0.001222 & 0.000798 & 0.000870 & 0.000707 \\
\hline Mn [\%] & 0.018 & 0.023 & 0.023 & 0.013 & 0.017 & 0.017 & 0.011 & 0.010 & 0.009 \\
\hline B [\%] & 0.153 & 0.109 & 0.091 & 0.082 & 0.071 & 0.138 & 0.097 & 0.074 & 0.059 \\
\hline Мo [\%] & 0.033 & 0.062 & 0.047 & 0.049 & 0.038 & 0.048 & 0.033 & 0.028 & 0.019 \\
\hline Stipe $\mathrm{Na}[\%]$ & 0.592 & 0.599 & 1.628 & 2.914 & 6.342 & 1.452 & 25.705 & 46.203 & 54.12 \\
\hline $\mathbf{K}[\%]$ & 43.408 & 49.662 & 45.685 & 43.557 & 42.638 & 47.613 & 35.876 & 25.267 & 21.766 \\
\hline $\mathrm{Ca}[\%]$ & 13.201 & 11.048 & 10.353 & 9.536 & 8.478 & 10.910 & 7.729 & 5.654 & 3.838 \\
\hline $\mathrm{Mg}[\%]$ & 13.244 & 13.449 & 10.838 & 10.387 & 9.465 & 14.404 & 10.212 & 7.148 & 4.240 \\
\hline $\mathbf{P}[\%]$ & 29.453 & 25.120 & 31.387 & 33.496 & 32.982 & 25.464 & 20.361 & 15.643 & 15.969 \\
\hline $\mathrm{Fe}[\%]$ & 0.000047 & 0.000057 & 0.000101 & 0.000088 & 0.000091 & 0.000014 & 0.000059 & 0.000080 & 0.000430 \\
\hline Mn [\%] & 0.003 & 0.004 & 0.003 & 0.003 & 0.003 & 0.011 & 0.010 & 0.007 & 0.006 \\
\hline B [\%] & 0.077 & 0.091 & 0.083 & 0.086 & 0.073 & 0.094 & 0.071 & 0.049 & 0.040 \\
\hline Mo [\%] & 0.023 & 0.027 & 0.023 & 0.021 & 0.019 & 0.053 & 0.037 & 0.029 & 0.021 \\
\hline Leaf $\mathrm{Na}[\%]$ & 0.397 & 0.468 & 0.660 & 1.273 & 2.874 & 0.525 & 20.327 & 32.257 & 47.415 \\
\hline $\mathbf{K}[\%]$ & 26.168 & 25.301 & 26.243 & 25.347 & 25.346 & 30.571 & 24.602 & 20.640 & 16.274 \\
\hline $\mathrm{Ca}[\%]$ & 16.976 & 15.624 & 16.349 & 16.544 & 12.526 & 17.893 & 12.568 & 10.549 & 8.738 \\
\hline $\mathrm{Mg}[\%]$ & 20.581 & 20.303 & 19.034 & 18.621 & 18.222 & 26.681 & 19.342 & 15.346 & 10.356 \\
\hline $\mathrm{P}[\%]$ & 35.292 & 37.513 & 36.984 & 37.500 & 40.427 & 23.410 & 22.510 & 20.682 & 16.866 \\
\hline $\mathrm{Fe}[\%]$ & 0.000341 & 0.000330 & 0.000432 & 0.000338 & 0.000282 & 0.000253 & 0.000234 & 0.000315 & 0.000536 \\
\hline Mn [\%] & 0.006 & 0.007 & 0.007 & 0.007 & 0.004 & 0.018 & 0.016 & 0.015 & 0.013 \\
\hline B [\%] & 0.538 & 0.729 & 0.673 & 0.664 & 0.557 & 0.728 & 0.524 & 0.426 & 0.285 \\
\hline Мo [\%] & 0.042 & 0.053 & 0.049 & 0.044 & 0.042 & 0.174 & 0.110 & 0.084 & 0.051 \\
\hline
\end{tabular}


Table 3. The percentages of different anions in root, stem, stipe and leaf of G. gracili seedlings under different type salts stresses. Neutral salts stress: $\mathrm{NaCl}: \mathrm{Na}_{2} \mathrm{SO}_{4}=1: 1$; Alkaline salts stress: $\mathrm{NaHCO}_{3}: \mathrm{Na}_{2} \mathrm{CO}_{3}=1: 1$.

\begin{tabular}{|c|c|c|c|c|c|c|c|c|c|}
\hline $\begin{array}{c}\mathrm{Na}^{+} \text {concentration } \\
(\mathrm{mM})\end{array}$ & $\mathbf{0}$ & $\begin{array}{l}\text { NS } \\
30\end{array}$ & 60 & 90 & 120 & $\begin{array}{l}\text { AS } \\
30\end{array}$ & 60 & 90 & 120 \\
\hline $\operatorname{Root~} \mathrm{Cl}^{-}[\%]$ & 10.407 & 21.004 & 22.320 & 25.674 & 21.981 & 7.440 & 10.205 & 14.997 & 19.525 \\
\hline $\mathrm{NO}_{3}{ }^{-}[\%]$ & 39.266 & 34.208 & 27.729 & 25.057 & 23.381 & 44.580 & 31.986 & 30.505 & 24.608 \\
\hline $\mathrm{H}_{2} \mathrm{PO}_{4}{ }^{-}[\%]$ & 26.227 & 20.740 & 28.183 & 27.748 & 33.891 & 18.926 & 17.217 & 15.674 & 20.333 \\
\hline $\mathrm{SO}_{4}{ }^{2-}[\%]$ & 9.542 & 9.903 & 10.230 & 10.993 & 11.105 & 11.164 & 10.101 & 12.874 & 10.790 \\
\hline $\left.\mathrm{C}_{2} \mathrm{O}_{4}^{2-}[\%]\right]$ & 14.560 & 14.145 & 11.537 & 10.528 & 9.642 & 17.890 & 30.491 & 25.950 & 24.744 \\
\hline Stem $\mathrm{Cl}^{-}[\%]$ & 8.681 & 9.174 & 9.693 & 9.507 & 12.388 & 9.449 & 9.372 & 8.926 & 8.660 \\
\hline $\mathrm{NO}_{3}{ }^{-}[\%]$ & 19.927 & 20.062 & 19.978 & 18.874 & 15.245 & 18.876 & 16.149 & 15.393 & 15.107 \\
\hline $\mathrm{H}_{2} \mathrm{PO}_{4}^{-}[\%]$ & 32.348 & 28.451 & 30.973 & 31.556 & 33.736 & 29.145 & 25.834 & 25.154 & 25.573 \\
\hline $\mathrm{SO}_{4}{ }^{2-}[\%]$ & 12.467 & 14.104 & 14.090 & 14.621 & 14.542 & 14.735 & 15.211 & 14.564 & 16.389 \\
\hline $\mathrm{C}_{2} \mathrm{O}_{4}{ }^{2-}[\%]$ & 26.578 & 28.209 & 25.266 & 25.442 & 24.090 & 27.795 & 33.435 & 35.963 & 34.271 \\
\hline Stipe $\mathrm{Cl}^{-}[\%]$ & 8.125 & 8.376 & 11.828 & 11.466 & 13.241 & 9.231 & 9.089 & 9.862 & 8.666 \\
\hline $\mathrm{NO}_{3}{ }^{-}[\%]$ & 37.915 & 38.181 & 33.471 & 33.953 & 31.300 & 31.068 & 28.622 & 26.311 & 28.455 \\
\hline $\mathrm{H}_{2} \mathrm{PO}_{4}^{-}[\%]$ & 17.742 & 23.983 & 28.983 & 29.549 & 30.133 & 26.355 & 25.740 & 25.031 & 23.562 \\
\hline $\mathrm{SO}_{4}{ }^{2-}[\%]$ & 14.947 & 13.357 & 12.541 & 13.009 & 12.969 & 13.858 & 14.566 & 17.207 & 16.121 \\
\hline $\mathrm{C}_{2} \mathrm{O}_{4}{ }^{2-}[\%]$ & 21.271 & 16.103 & 13.178 & 12.023 & 12.357 & 19.487 & 21.982 & 21.590 & 23.185 \\
\hline Leaf $\mathrm{Cl}^{-}[\%]$ & 8.506 & 10.133 & 10.521 & 11.719 & 14.078 & 11.508 & 9.915 & 9.450 & 7.694 \\
\hline $\mathrm{NO}^{-}[\%]$ & 16.163 & 13.949 & 14.153 & 13.475 & 12.570 & 12.102 & 12.099 & 13.236 & 13.947 \\
\hline $\mathrm{H}_{2} \mathrm{PO}_{4}^{-}[\%]$ & 40.215 & 38.664 & 40.371 & 40.074 & 38.602 & 32.310 & 26.873 & 26.986 & 27.290 \\
\hline $\mathrm{SO}_{4}{ }^{2-}[\%]$ & 14.210 & 13.407 & 16.163 & 17.023 & 14.645 & 16.178 & 21.709 & 22.229 & 17.583 \\
\hline $\mathrm{C}_{2} \mathrm{O}_{4}{ }^{2-}[\%]$ & 20.905 & 23.847 & 18.792 & 17.710 & 20.104 & 27.902 & 29.405 & 28.098 & 33.485 \\
\hline
\end{tabular}

Under AS, the accumulated cations in roots were mainly $\mathrm{Na}^{+}$and $\mathrm{K}^{+}$atlow concentrations and $\mathrm{Na}^{+}$ athigh stress concentrations, and the accumulated anions were mainly $\mathrm{NO}_{3}$-and $\mathrm{H}_{2} \mathrm{PO}_{4}-$. The main accumulated cations in stems and petioles were $\mathrm{P}^{3+}$ and $\mathrm{K}^{+}$at low concentrations and $\mathrm{Na}^{+}$at high stress concentrations, and the accumulated anions were $\mathrm{NO}_{3}-$ and $\mathrm{H}_{2} \mathrm{PO}_{4}$-. The accumulated cations in leaves were mainly $\mathrm{Mg}^{2+}$ and $\mathrm{K}^{+}$at low concentrationsand $\mathrm{Na}^{+}$at high stress concentrations, and the accumulated anions were $\mathrm{NO}_{3}-$ and $\mathrm{H}_{2} \mathrm{PO}_{4}-$. Under AS, the percentage of $\mathrm{Na}^{+}, \mathrm{C}_{2} \mathrm{O}_{4}^{2-}, \mathrm{Cl}^{-}$and $\mathrm{SO}_{4}^{2-}$ in roots and stem sincreased, but the percentage of $\mathrm{K}^{+}, \mathrm{Mg}^{2+}, \mathrm{Ca}^{2+}, \mathrm{P}^{3+}$, $\mathrm{Mo}^{2+}, \mathrm{NO}_{3}-$ and $\mathrm{H}_{2} \mathrm{PO}_{4}$-decreased. The percentages of $\mathrm{Na}^{+}, \mathrm{SO}_{4}{ }^{2-}, \mathrm{C}_{2} \mathrm{O}_{4}{ }^{2-}, \mathrm{Cl}^{-}$and $\mathrm{H}_{2} \mathrm{PO}_{4}-$ in petioles increased, and the percentages of $\mathrm{K}^{+}, \mathrm{Mg}^{2+}, \mathrm{Ca}^{2+}, \mathrm{P}^{3+}$, $\mathrm{Mo}^{2+}$ and $\mathrm{NO}_{3}-$ decreased. The percentage of $\mathrm{Na}^{+}$, $\mathrm{Mo}^{2+}, \mathrm{SO}_{4}^{2-}, \mathrm{C}_{2} \mathrm{O}_{4}^{2-}$ in leaves increased, and the percentage of $\mathrm{K}^{+}, \mathrm{Mg}^{2+}, \mathrm{Ca}^{2+}, \mathrm{P}^{3+}, \mathrm{NO}_{3}-$ and $\mathrm{H}_{2} \mathrm{PO}_{4}-$ decreased. Compared with other cations, the percentages of $\mathrm{Fe}^{2+}, \mathrm{Mn}^{2+}, \mathrm{B}^{3+}$ and $\mathrm{Mo}^{2+}$ were very small, less than $1 \%$ of the total cations. The percentage of $\mathrm{Fe}^{2+}$ content was the smallest, and its percentage content had no obvious difference with the control group (Table 2-3). 


\section{Discussion}

High salt-stress generally leads to growth arrest and even plant death (Cuartero and Fernández-Muñoz, 1998; Maggio et al., 2007). However, in the present study, there was no decrease in $R G R$ of $G$. gracilis under NS and AS stress. The $R G R$ value reflects the life-sustaining activities of a plant, and is considered as an optimum index for the degree of stress and plant responses to stresses (Yang et al., 2008). Shoot height and root length showed the direct performance of in vitro plants based on the salinity-alkalinity stress influence degree of physiology. The roots conta in the first perceptible stress information and influence on growth. The decrease of $R G R$ with increasing stress was also supported by the change in shoot height and root length. However, the fact that the $R G R$ decrease under AS was greater than under NS, implies not only that NS and AS stresses are distinct, but also the resistance of G. gracilis to NS stress is stronger than to SA stress. The injurious effect caused by AS was greater than that of NS at the same salinity concentration, consistent with previous reports (Shi and Sheng, 2005; Yang et al., 2007; Wang et al., 2011).

The different injurious effects of the two stresses may be related to different mechanisms. The injurious effects of salinity are commonly thought to be a result of low water potentials and ion toxicities (Munns and Tester, 2008). The AS exerts the same stress factors as NS but with the added influence of high-pH stress. The high-pH environment surrounding the roots not only can directly cause some ions, such as $\mathrm{Ca}^{2+}, \mathrm{Mg}^{2+}$, $\mathrm{HPO}_{4}{ }^{2-}$ and $\mathrm{H}_{2} \mathrm{PO}_{4}$, to precipitate (Shi and Wang, 2005), but also may create some microelement toxicity, which can be detrimental to plants, especially for root growth. Plant survival under alkali stress, therefore, depends on not only its capability to cope with water stress and ion toxicity, but also its resistance to high $\mathrm{pH}$ levels. Therefore, to adapt to the AS stress environment, plants need to expend more material and energy than to adapt to NS stress, and this might bee reason for the lower $R G R$ value under AS stress than under NS stress, as observed in this research. Data show high $\mathrm{pH}$ levels as an important factor in limiting plant growth and development under alkaline conditions (Yang et al., 2007, 2008). High pH clearly affects plant growth differently at various developmental stages.

Plants in saline conditions usually accumulate inorganic ions in vacuoles to decrease their cell water potential, because the energy consumption for absorbing inorganic ions is far less than for synthesizing organic compounds. If excessive amounts of ions enter the plant, they rise to toxic levels, inhibit photosynthesis and thus reduce the growth rate (Munns and Tester, 2008). $\mathrm{Na}^{+}$ is the main poisonous ion in salinized soil. (Zhang et al. 2014) Low $\mathrm{Na}^{+}$and high $\mathrm{K}^{+}$levels in the cytoplasm are essential to maintain a number of enzymatic processes (James et al., 2006; Hussain et al., 2013).

Ionic imbalance in plants is mainly caused by the influx of superfluous $\mathrm{Na}^{+}$(Munns and Tester, 2008; Blumwald, 2000). Plants in saline conditions usually accumulate inorganic anions, such as $\mathrm{Cl}^{-}$(Santa-Cruz et al., 2002), $\mathrm{NO}_{3}-$, and $\mathrm{SO}_{4}{ }^{2-}$, or synthesize organic anions to neutralize the high concentrations of cations and maintain ionic balance (Yang et al., 2007).

A stable internal environment, as a result of intracellular ion balance, is necessary for plants to maintain a normal metabolism (Yang et al., 2007). In a living plant, as long as the plant can adapt to the environment, the proportion of ions in its tissue should be stable regardless of how the environmental $\mathrm{pH}$ value changes. The dominant intracellular cations under control, in this study, were $\mathrm{P}^{+}$and $\mathrm{K}^{+}$, contributing $>70 \%$ of the total positive charge. However, while the $\mathrm{Na}^{+}$concentrations increased with increasing stress, $\mathrm{K}^{+}$concentrations decreased. The $\mathrm{Na}^{+}$and $\mathrm{K}^{+}$were the dominant intracellular cations under both NA and SA stresses. 
The contribution of $\mathrm{Fe}^{2+}, \mathrm{Mn}^{2+}, \mathrm{B}^{3+}$ and $\mathrm{Mo}^{2+}$ to the total positive charge was minimal $(<1 \%)$. This is in contrast to that observed in K. sieversiana (Yang et al., 2007) where the contribution of $\mathrm{K}^{+}$to the total positive charge was dramatically greater than that in G. glauca.

At lower stress intensities, the effects of both salts on the $\mathrm{Na}^{+}$content and $\mathrm{Na}^{+} / \mathrm{K}^{+}$of G. gracilis were similar. But when the salinity was higher than $60 \mathrm{mM}$, as the salinity increased, the $\mathrm{Na}^{+}$contents and $\mathrm{Na}^{+} / \mathrm{K}^{+}$ values increased slowly under NS, but sharply under AS. This implied that the high $\mathrm{pH}$ level of AS might interfere with control of $\mathrm{Na}^{+}$uptake in the shoots and increase the intracellular $\mathrm{Na}^{+}$content to a toxic level. This could explain some of the damage that emerged in higher AS environments. James et al. (2006) also reported that the photosynthetic capacity was related to the cellular and subcellular partitioning of $\mathrm{Na}^{+}, \mathrm{K}^{+}$ and $\mathrm{Cl}^{-}$. Moreover, the high $\mathrm{pH}$ level led to the $\mathrm{H}^{+}$ deficit outside the roots and may limit the $\mathrm{Na}^{+}$extrusion from the root cytosol to the external environment. This may be why the injurious effects caused by AS were greater than those of NS. However, the behavior of G. gracilis was significantly different from that of Kochia sieversiana, a naturally alkali-resistant halophyte (Yang et al., 2007). However, the effects of both stresses on $\mathrm{Na}^{+}-\mathrm{K}^{+}$selective absorption and other $K$. sieversiana responses were similar. This indicates that $K$. sieversiana root cells may be resistant to the highpH surrounding the roots, and prevented from invading the intracellular environment. Therefore, we propose that the high-pH environment surrounding the roots is an important physiological mechanism for plant resistance to AS. The process of $\mathrm{pH}$ adjustment may occur outside the roots, in the roots or in both simultaneously. However, the mechanisms governing the ionic balance under both stresses were different. That the dominant intracellular anion in G. gracilis roots, stems and leaves under both stresses was similar to in the control and that the stress intensity did not have an effect on the anions' proportions suggested that $G$. gracilis was able to maintain the ionic balance in cells, not only under NS, but also under AS, even at $\mathrm{pH}>9.88$. In addition, the dominant anion adjustment differed among roots, stems and leaves. The present results indicated that the roots of G. gracilis accumulated $\mathrm{NO}_{3}$-and $\mathrm{H}_{2} \mathrm{PO}_{4}$ - to maintain the intracellular ionic balance under both saline and alkaline conditions. While in stems and leaves, $\mathrm{C}_{2} \mathrm{O}_{4}{ }^{2-}$ and $\mathrm{H}_{2} \mathrm{PO}_{4}$-were accumulated to maintain the intracellular ionic balance. The dominant intracellular anions in $G$. gracilis stipes were $\mathrm{NO}_{3}-$ and $\mathrm{C}_{2} \mathrm{O}_{4}{ }^{2-}$ under the control treatment, while $\mathrm{NO}_{3}$-and $\mathrm{H}_{2} \mathrm{PO}_{4}-$ accumulated under both stress.

While the $\mathrm{SO}_{4}^{2-}$ concentrations increased with the increasing stress, the $\mathrm{NO}_{3}$-concentrations decreased. However, under AS stress, the $\mathrm{Cl}^{-}$and $\mathrm{H}_{2} \mathrm{PO}_{4}$-concentrations decreased, and G. gracilis might have enhanced the $\mathrm{C}_{2} \mathrm{O}_{4}^{2-}$ concentration to compensate for the shortage of inorganic anions. The accumulation of $\mathrm{C}_{2} \mathrm{O}_{4}^{2-}$ in $\mathrm{G}$. gracilis may be a response to an inorganic anion deficit. Under NS stress, the $\mathrm{C}_{2} \mathrm{O}_{4}{ }^{2-}$ concentrations decreased, and G. gracilis might have enhanced $\mathrm{Cl}^{-}$and $\mathrm{H}_{2} \mathrm{PO}_{4}-$ concentrations to compensate for the shortage of inorganic anions. The accumulation of $\mathrm{Cl}^{-}$and $\mathrm{H}_{2} \mathrm{PO}_{4}-$ in G. gracilis may be a response to an inorganic anion deficit. Therefore, $\mathrm{Cl}^{-}, \mathrm{H}_{2} \mathrm{PO}_{4}^{-}$ and $\mathrm{C}_{2} \mathrm{O}_{4}^{2-}$ accumulations may result from a negative charge deficit, and the $\mathrm{C}_{2} \mathrm{O}_{4}{ }^{2-}$ metabolic regulation may play an important role in maintaining the ionic balance.

\section{Conclusion}

In summary, the effects of different types of salt stress onthe growth of G. gracilis seedlings were significantly different. Under alkali salts stress, the growth of $G$. gracilis seedlings was more intensely inhibited than under neutral salts stress, which related to specific ion 
accumulations under different types of salt stress. The accumulation of $\mathrm{Na}^{+}$and $\mathrm{Cl}^{-}$were significant under neutral salts stress. However, under alkali salts stress, $\mathrm{Na}^{+}$accumulated but $\mathrm{K}^{+}$declined, and the $\mathrm{Na}^{+} / \mathrm{K}^{+}$increased significantly, which showed that the damage mechanism of both types of salt stresses on plants were different. Due to the high $\mathrm{pH}$ under alkali salts treatments, the accumulation of anions in plants was breached. Under the different types of salt stress, $G$. gracilis seedlings had obviously different ionic balances and specific ion, such as $\mathrm{Mn}^{2+}$ and $\mathrm{Mo}^{2+}$, accumulation capabilities, which were associated with the relief of the high $\mathrm{pH}$ stress. Due to specific ion levels slowly dropping and accumulation specificity, G. gracilis seedlings also showed some adaptability in growth under both types of salt stress, though the adaptability of $G$. gracilis to the neutral salts stress was better than to the alkali salts stress.

\section{Acknowledgements}

This research was supported by the National Natural Science Foundation of China (No. 31270366).

\section{References}

Blumwald, E. 2000. Sodium transport and salt tolerance in plants. Curr Opin Cell Biol. 12, 43-434.

Brand, J.D., Tang, C., Rathjen, A.J. 2002. Screening rough-seeded lupins (Lupinus pilosus Murr. and Lupinus atlanticus Glads.) for tolerance to calcareous soils. Plant Soil. 245, 261-275.

Campbell, S.A., Nishio, J.N. 2000. Iron deficiency studies of sugar beet using an improved sodium bicarbonate-buffered hydroponics growth system. Plant Nutr. 23, 741-757.

Chen, W.C., Cui, P.J., Sun, H.H., Guo, W.Q., Yang, C.W., Jin, H., Fang, B., Shi, D.C. 2009. Comparative effects of salt and alkali stresses on organic acid accumulation and ionic balance of seabuckthorn (Hippophae rhamnoides L.). Industrial Crops and Products. 30, 351-358.

Cuartero, J., Fernández-Muñoz, R. 1998. Tomato and salinity. Sci. Hortic. 78, 83-125.

El-Samad, H. M. A., Shaddad, M. A. K. 1996. Comparative effect of sodium carbonate, sodium sulphate, and sodium chloride on the growth and related metabolic activities of pea plants. Plant Nutr. 19, 717-728.

Gao, C., Wang, Y., Liu, G., Yang, C., Jiang, J., Li, H. 2008. Expression profiling of salinity-alkali stress responses by large-scale expressed sequence tag analysis in Tamarix hispid. Plant Mol. Biol. 66, 245-258.

Ge, Y., Li, J. 1990. A preliminary study on the effects of halophytes on salt accumulation and desalination in the soil of Songnen Plain, northeast China. Acta Pratacult. Sin. 1, 70-76.

Hartung, W., Leport, L., Ratcliffe, R.G., Sauter, A., Duda, R., Turner, N. C. 2002. Abscisic acid concentration, root $\mathrm{pH}$ and anatomy do not explain growth differences of chickpea (Cicer arietinum L.) and lupin (Lupinus angustifolius L.) on acid and alkaline soils. Plant Soil. 240, 191-199.

Huang, J.C., Lai, W.A., Singh, S., Hameed, A., Young, C.C. 2013. Response of mycorrhizal hybrid tomato cultivars under saline stress. Journal of Soil Science \& Plant Nutrition. 13, 469-484.

Hussain, Z., Khattak, R.A., Irshad, M., Eneji, A. E.2013. Ameliorative effect of potassium sulphate on the growth and chemical composition of wheat (triticum aestivum L.) in salt-affected soils. Journal of Soil Science \& Plant Nutrition. 13, 401-415.

James, R.A., Munns, R., Von-Caemmerer S, Trejo, C., Miller, C., Condon, T. 2006. Photosynthetic capacity is related to the cellular and subcellular partitioning of $\mathrm{Na}^{+}, \mathrm{K}^{+}$and $\mathrm{Cl}^{-}$in salt-affected 
barley and durum wheat. Plant Cell Environ. 29, 2185-2197.

Kingsbury, R.W., Epstein, E., Peary, R. W. 1984. Physiological responses to salinity in selected lines of wheat. Plant Physiology. 74, 417-423.

Läuchli, A., Lüttge, U. 2002. Salinity in the soil environment. In: Salinity: Environment-PlantsMolecules, Kluwer Academic Publ, Boston, 21$23 \mathrm{p}$.

Li, C.Y., Fang, B., Yang, C.W., Shi, D.C., Wang, D.L. 2009. Effects of various salt-alkaline mixed stresses on the state of mineral elements in nutrient solutions and the growth of alkali resistant halophyte Chloris virgata. Journal of Plant Nutrition. 32, 1137-1147.

Liu, S., Dong, Y.J., Xu, L.L., Kong, J., Bai, X. Y. 2013. Roles of exogenous nitric oxide in regulating ionic equilibrium and moderating oxidative stress in cotton seedlings during salt stress. Journal of Soil Science and Plant Nutrition. 13, 929-941.

Maggio, A., Raimondi, G., Martino, A., De Pascale, S.2007. Salt stress response in tomato beyond the salinity tolerance threshold. Environ. Exp. Bot. 59, 276-282.

Mekawy, A.M.M., Assaha, D.V.M., Yahagi, H., Tada,Y., Ueda, A., Saneoka, H. 2015. Growth,physiological adaptation, and gene expression analysis of two Egyptian rice cultivars under salt stress. Plant Physiology and Biochemistry. $87,17-25$.

Munns, R., Tester, M. 2008. Mechanisms of salinity tolerance. Plant Biol. 59, 651-681.

Niu, X., Bressan, R.A., Hasegawa, P.M., Pardo, J.M. 1995. Ion homeostasis in $\mathrm{NaCl}$ stress environments. Plant Physiol. 109, 735-742.

Nuttall, G., Armstrong, R.D. 2003. Evaluating physicochemical constraints of Calcarosols on wheat yield in the Victorian southern Mallee. Aust J Agr Res. 5, 487-497.

Rao, P.S., Mishra, B., Gupta, S.R., Rathore, A. 2008 Reproductive stage tolerance to salinity and alkalinity stresses in rice genotypes. Plant Breeding. 127, 256-261.

Santa-Cruz, A., Martinez-Rodriguez, M. M., PerezAlfocea, F., Romero-Aranda, R., Bolarin, C.M. 2002. The rootstock effect on the tomato salinity response depends on the shoot genotype. Plant Sci. 162, 825-831.

Shi, D.C., Sheng, Y.M. 2005. Effect of various saltalkaline mixed stress conditions on sunflower seedlings and analysis of their stress factors. Environ. Exp. Bot. 54, 8-21.

Shi, D.C., Wang, D.L. 2005. Effects of various saltalkali mixed stresses on Aneurolepidium chinense (Trin.) Kitag. Plant Soil. 271, 15-26.

Wang, S.M., Wan, C.G., Wang, Y. R. 2004. The characteristics of $\mathrm{Na}^{+}, \mathrm{K}^{+}$and free proline distribution in several drought-resistant plants of the Alxa Desert, China. Journal of Arid Environments. 3, 525-539.

Wang, H., Wu, Z.H., Chen, Y.M., Yang, C.W., Shi, D. C.2011. Effects of salt and alkali stresses on growth and ion balance in rice (Oryza sativa L.). Plant soil and environment. 6, 286-294

Wang, X.P., Chen, W.C., Zhou, Y., Han, J.Y., Zhao, J., Shi, D.C., Yang, C.W. 2012. Comparison of adaptive strategies of alfalfa (Medicago sativa L.) to salt and alkali stresses. Australian Journal of Crop Science. 2, 309-315.

Wu, G., Zhou, Z.D., Chen, P., Tang, X.L., Shao, H.B., Wang, H.Y. 2014. Comparative ecophysiological study of salt stress for wild and cultivated soybean species from the Yellow River Delta, China. The Scientific World Journal. http://dx.doi.org/10.1155/2014/651745. 
Wu, X.L., He, C.Y., Chen, S. Y. 2001. The diversity and evolution relation of Glycine. Nature Science Progress. 7, 689-698.

Yang, C. W., Shi, D. C., Wang, D. L. 2008. Comparative effects of salt stress and alkali stress on growth, osmotic adjustment and ionic balance of an alkali resistant halophyte Suaeda glauca (Bge). Plant Growth Regul. 56, 179-190.

Yang, C.W., Chong, J.N., Kim, C.M., Li, C.Y., Shi, D.C., Wang, D. L.2007. Osmotic adjustment and ion balance traits of an alkali resistant halophyte Kochia sieversiana during adaptation to salt and alkali conditions. Plant Soil. 294, 263-276.
Zhang, T., Wan, S., Kang, Y., Feng, H. 2014. Urease activity and its relationships to soil physiochemical properties in a highly saline-sodic soil. Journal of Soil Science \& Plant Nutrition. 14, 304-315.

Zhang, Z. H., Wang, H., Tang, Z. H., Zhu, Y. G., Liu, Y. 2014. High $\mathrm{NaHCO}_{3}$ stress causes direct injury to Nicotiana tabacum roots. Journal of Plant Interactions. 1, 56-61.

Zubair, M., Anwar, F., Ashraf, M., Ashraf, A., Chatha, S. A.S. 2012. Effect of green and farmyard manure on carbohydrates dynamics of salt-affected soil. Journal of Soil Science \& Plant Nutrition. 12, 497-510. 